\title{
The Role Formation of Methylglyoxal, Carbonyl Compound, Hydrogen Peroxide and Advance Oxidation Protein Product Induced Cadmium in Ovarian Rat
}

\author{
A. H. Husna, E. A. Ramadhani, Eva D. T., A. F. Yulita, and E. Suhartono
}

\begin{abstract}
Cadmium (Cd) is a heavy metal that be a source of concern for industrial workers and it was proposed in the formation of advance glycation end products (AGEs) such as methylglyoxal (MG). In the other hand the exposure of $\mathrm{Cd}$ also induced the formation of Hydrogen Peroxide $\left(\mathrm{H}_{2} \mathrm{O}_{2}\right)$, Carbonyl Compound (CC) and Advance Oxidation Protein Products (AOPP). The role of $\mathrm{Cd}$ in the formation of $\mathrm{MG}, \mathrm{H}_{2} \mathrm{O}_{2}, \mathrm{CC}$ and AOPP in ovarian has not been much studied. Thus, our study aims to measure the formation rate of $\mathrm{MG}, \mathrm{H}_{2} \mathrm{O}_{2}, \mathrm{CC}$ and $\mathrm{AOPP}$ in ovarian rat. Female Rattus novergicus was divided in two groups, one control groups and one case group. Furthermore we set MG, CC, $\mathrm{H}_{2} \mathrm{O}_{2}$ and AOPP as a biomarker of ovarian cell damage. For analyzing of the data, SPSS software version 17 was used and was examined by Mean-Whitney test. For all outcomes, a nominal $p$-value of $p<0,05$ was considered significant. The resulted showed that there are a significance differences of MG, CC, $\mathrm{H}_{2} \mathrm{O}_{2}$ and AOPP between case and control group.
\end{abstract}

Index Terms-AOPP, cadmium, hydrogen peroxide, and methylglyoxal.

\section{INTRODUCTION}

Cadmium is one of the most toxic substances in the environment caused its toxic effects on multiple organ systems and long elimination half-time. The Agency for Toxic Substances and Disease Registry (ATSDR) has listed Cd among the top seven of the 275 most hazardous substances in the environment. This metal is used in many occupations, including semiconductor manufacturing, welding, soldering, ceramics and painting. In the industry, $\mathrm{Cd}$ is hazardous both by inhalation and ingestion and can cause acute and chronic intoxications. $\mathrm{Cd}$ dispersed in the environment can persist in soils and sediments for decades. When taken up by plants, $\mathrm{Cd}$ concentrates along the food chain and ultimately accumulates in the body of people eating contaminated foods. $\mathrm{Cd}$ is also present in tobacco smoke, further contributing to human exposure. Further, the most salient toxicological property of $\mathrm{Cd}$ is its exceptionally long half-life in the human body. Once absorbed, Cd irreversibly accumulates in the human body, in particularly in kidneys and other vital organs such the lungs or the liver. Acute exposure to $\mathrm{Cd}$ in vivo causes dysuria, polyuria, chest pain, fatigue, headache, and hepatooxidative

Manuscript received October 24 2013; revised January 17, 2014.

The authors are with Faculty of Medicine Lambung Mangkurat University South Kalimantan, Indonesian (e-mail: annisa_halida@rocketmail.com, earahmadhani@gmail.com, evadamay antitumbelaka@rocketmail.com, alvitayulita@ymail.com, ekoantioxidant @ gmail.com).
[1]-[3].

Cadmium also affects reproductive organs especially ovarium. Basic histological studies showed that in the ovary cadmium causes a decrease in the number of primary follicles. Massanyi et al. in their research showed that the number of atretic follicles was significantly higher in all groups administered cadmium and the diameter of the follicles was significanlty smaller in the primary follicles of group $\mathrm{C}$ compared with control group [4], [5]. The mechanism cadmium damage the ovarium might through the formation of advance glycation end products (AGEs) by nonenzymatic reaction and the formation of advance oxidation protein products (AOPP) [6].

The nonenzymatic reaction between reducing sugars and proteins, known as glycation, has received increased attention in nutritional and medical research. Nonenzymatic glycation is a complex series of reactions between reducing sugars and amino compounds. As the first step of AGEs formation, the free amino groups of proteins in the tissues react with a carbonyl group of reducing sugars, such as glucose, to form glucosamines via a Schiff base by Amadori rearrangement. Both Schiff base and Amadori product further undergo a series of reactions through dicarbonyl intermediates [e.g., glyoxal (GO), methylglyoxal (MG) and 3-deoxyglucosone], to form AGEs. GO and MG, the two major $\alpha$-dicarbonyl compounds found in the human body, are extremely reactive and readily modify lysine, arginine, and cysteine residues of proteins [7]. Reactive carbonyl compounds such as GO and MG have recently attracted much attention because of their possible clinical significance in chronic and age-related diseases [8]-[10]. For example, MG mediates vascular inflammation in human endothelial cells [11], gastric ulcer [12], and renal disease [13].

In recent years, a number of protein crosslinks have been isolated that are thought involve the MG. MG is a potent protein and nucleic acid modifying agent found in all mammalian systems as a consequence of energy metabolism. MG is produced through spontaneous phosphate elimination from glycolytic pathway intermediates. MG levels also respond to signaling events associated with cell death, indicating that anabolic activities for MG production that may be present in mammalian systems as they are in bacteria, although that is yet to be demonstrated. The physiological concentration of MG is thought to range between $256 \mathrm{nM}$ in blood (2.4 $\mu \mathrm{M}$ in diabetics), $1 \mu \mathrm{M}$ in plasma and $15 \mu \mathrm{M}$ in urine in healthy human. However, up to $310 \mu \mathrm{M}$ has been reported where assay systems have quantified reversibly protein-bound methylglyoxal along with unbound. 
Ninety-nine percent of methylglyoxal is thought exist in reversibly bound state to protein or other biological ligands [14], [15].

The previous study described that the reaction of MG with ceruloplasmin may lead to decreased feroxidase activity in vitro [16]. In addition, the ferritin/MG/lysine system may lead to oxidative DNA damage via the generation of ROS by the Fenton-like reaction of free iron ions released from oxidatively damaged ferritin [17]. Based on previous research, methylglyoxal formation can be accelerated by metals in vitro. The proposed mechanism explained that the metal Mn+ (e.g., $\mathrm{Fe}^{2+}, \mathrm{Cu}^{2+}$, and so on) can catalyze the 2,3-enediol and formed MG and hydroperoxide [18].

Exposure of $\mathrm{Cd}$ activated cells to form a reactive oxygen compounds. This event called respiratory burst involving the NADPH oxidase activation. At the respiratory burst, there was a rapid uptake of molecular oxygen and transformation into reactive oxygen compounds, which is a representation of the host defense mechanisms in the inflammatory site. It is important that relevant reactive oxygen compounds physiological concentrations able to modulate the redox-sensitive signaling cascade and improve immunological cellular function [19].

Reactive oxygen species such as hydrogen peroxide, superoxide anion, hydroxyl radical, etc can trigger oxidative damage to macromolecules, leading to lipid peroxidation, amino acid chains oxidation, cross links protein formation, polypeptide chain oxidation forming protein fragmentation, DNA strands ruptured. Radical oxygen compounds were involved in production of advance oxidation protein products (AOPP) [20].

AOPP is dityrosine containing cross linked protein products, a definition that is important as it excludes protein aggregates that are formed by disulphide bonds as a result of oxidative stress. Therefore, AOPP is a good oxidative stress marker, which originates under oxidative and carbonyl stress and increase global inflammatory activity. Several studies have used AOPP as a marker for several disease. AOPP has used as oxidative stress marker for nasal polyposis and acute coronary syndrome and also as inflammatory marker for liver cirrhosis and chronic renal failure [19], [20].

The use of Carbonyl Compound (CC), MG, hydrogen peroxide and AOPP as marker for the damage of ovarian cells were never been investigated, therefore a study to use this method as a marker for ovarian damage should be performed.

\section{MATERIAL AND MethodS}

The present study was a true experimental study with post-test-only and control group design to examine the impact of $\mathrm{Cd}$ exposure in ovarian rats (Rattus novergicus) with 10 weeks of age and weighing 200-250 grams. The study involved 2 groups of 40 female rats (Rattus novergicus), where one group was the control group, while the other was the case group with exposure of $\mathrm{Cd}$.

The control group rats were given $2 \mathrm{ml}$ of distilled water with a sonde every morning while in the treatment group rats were exposed $\mathrm{Cd}$. After 4 weeks, the mice were sacrificed using ether and then decapitated and performed surgery to take out the ovaries.

Ovaries were washed with phosphate buffer $\mathrm{pH} \mathrm{7,} \mathrm{then}$ ground up into a liquid. Then taken and $5 \mathrm{ml}$ centrifuge with a speed of $3500 \mathrm{rpm}$ for 10 minutes. After that, $200 \mathrm{~mL}$ of supernatant was taken for examination.

The damage of ovarian was measured from carbonyl compound, methylglyoxal, hydrogen peroxide and AOPP production.

\section{A. Data Analysis}

\section{1) Carbonyl compound assay}

Sample derivatization. Two 1-mg aliquots are needed for each sample to be assayed. Samples are extracted in a final concentration of $10 \%(\mathrm{w} / \mathrm{v})$ TCA. The precipitates are treated with $500 \mu \mathrm{L}$ of $0.2 \% \mathrm{DNPH}$ or $500 \mu \mathrm{L}$ of $2 \mathrm{M} \mathrm{HCl}$. Samples are incubated at room temperature for $1 \mathrm{~h}$ with vortexing at 5-min intervals. The proteins are then precipitated by adding $55 \mu \mathrm{L}$ of $100 \%$ TCA. The pellets are centrifuged and washed three times with $500 \mu \mathrm{L}$ of the ethanol:ethyl acetate mixture. The pellet is then dissolved in $600 \mu \mathrm{L}$ of $6 \mathrm{M}$ guanidine hydrochloride. The carbonyl content is determined by reading the absorbance at the optimum wavelength $390 \mathrm{~nm}$ [21].

\section{2) Methylglyoxal assay}

Methylglyoxals are estimated according to the modified method of Racker [22]. Twenty-five $\mu$ l of samples was added to $350 \mu \mathrm{l}$ of DNPH [0.1\% DNPH in $2 \mathrm{~N} \mathrm{HCl}]$. Then to each tube $2.125 \mathrm{ml}$ of distilled water was added. Then it was incubated for 15 minutes at $370 \mathrm{C}$. After the incubation $1.5 \mathrm{ml} 10 \% \mathrm{NaOH}$ was added and absorbance was read at $576 \mathrm{~nm}$ using spectrophotometer. MG levels are expressed in percent absorbance MG and dicarbonyl absorbance.

\section{3) Hydrogen peroxide assay}

$90 \mathrm{ml}$ of sample, $10 \mathrm{ml}$ of methanol and $900 \mathrm{ml}$ of xylenol orange reagent containing ferrous ions were added successively and absorbance was noted at $560 \mathrm{~nm}$ [23].

\section{4) АOPP assay}

Serum AOPP measurement were made by spectrophotometric methods as describe by Witko-Sarsat et al [24].

\section{B. Statistical Analysis}

Data are presented as means $\pm \mathrm{SD}$. The differences were examined by the Mann-Withney test. For all outcomes, a nominal $p$-value of $p<0.05$ was considered significant.

\section{RESULT AND DISCUSSION}

The average levels of MG and CC are presented in Table I.

TABLE I: MG AND CC LEVELS COMPARISON RESULT

\begin{tabular}{cccc}
\hline \hline Parameters & Control Group & Case Group & $P$ values \\
\hline Methylglyoxal & $0,005 \pm 0,003$ & $0,016 \pm 0,008$ & 0,000 \\
Carbonyl Compound & $0,718 \pm 0,643$ & $13,452 \pm 9,957$ & 0,000 \\
\hline \hline
\end{tabular}

Mann-Whitney test results showed (see Table I) that there were significant differences between case and control groups $(p<0.05)$.

Oxidants, including ROS, are constantly produced in cells through normal metabolic processes. Oxidative or oxidant stress occurs when the balance of oxidants within the cell 
exceeds the levels of antioxidants present. In many cases, reactive carbonyls are produced as a consequence of oxidative stress. The main mechanisms of endogenous reactive carbonyl production as a result of oxidant stress include the oxidation of lipids or lipid peroxidation, and the oxidation of glycation products or glycoxidation [25].

For the first mechanism, the peroxidation of membrane-derived lipid molecules is a well-studied consequence of increased intracellular oxidant levels. This process is known to give rise to many products through a series of iterative oxidation and cleavage reactions. The most commonly characterized products are aldehydes, derived from $\omega-6$ polyunsaturated fatty acids, such as malondialdehyde (MDA), hexanal, acrolein, glyoxal, crotonaldehyde, trans-2-nonenal, 4-oxo-2-nonenal, and 4-hydroxy-2-nonenal (HNE). MDA is the most common aldehyde produced, comprising of $70 \%$ of the total produced by lipid peroxidation. Hexanal contributes $15 \%$ and HNE contributes $5 \%$ of total aldehydes. Acrolein was identified as a lipid peroxidation product more recently through studies that examined the oxidation of low density lipoprotein (LDL) but was previously characterized as an environmental pollutant [25].

Many lipid peroxidation products have been detected at high levels in diseased states, and in fact several have the potential to be used as biomarkers of oxidative damage and disease progression. For example, in $\mathrm{AD}$ brain, there is an increase in levels of acrolein and studies have suggested that the levels of acrolein-modified proteins can be used as markers of the disease. Other reactive aldehydes, such as $\mathrm{HNE}$, are also elevated in AD brains, up to $3 \mathrm{nmol} / \mathrm{mg}$ of cell protein, and protein adducts of some aldehydes, such as crotonaldehyde, have been specifically detected in reactive astrocytes and microglia around senile plaques from $\mathrm{AD}$ brain In other diseases, for example in a rat model of hypertension, levels of HNE-protein adducts are significantly increased in plasma. HNE is also detected in fibrotic plaques and in oxidized LDL, supporting its role in the pathogenesis of atherosclerosis. In Type II diabetes, there is an elevation in the levels of HNEalbumin dducts in serum [25].

For the second mechanism, glucose combines a delicate balance chemical stability and chemical reactivity for metabolism synthesis. It also exists in several structural synthesis, divided based on the conformations: two major forms of pyranose (six-member rings with anomeric carbon at member rings with carbo position 1 , one minor form of furanose (five ring), and an open aldehyde. However aldehyde form is essential intermediate for conversion among these forms. The linear aldehyde glucose reactive structure that can bind to the amine group protein become glycated protein. This is consistent with the mechanism proposed by Voziyan et al. [6] can accelerate the formation of compounds dicarbonyl [e.g., glyoxal (GO), methylglyoxal (MG) and 3 deoxyglucosone].

MG as a side-product of glycolysis arises from an increased flux during hyperglycemia. Plasma MG levels are elevated in diabetic patients, which underscores the clinical and pathological significance of MG. An excess of MG and other reactive aldehydes such as glyoxal and 3-deoxyglucosone (3-DG) causes carbonyl overload and stress in such conditions as diabetes, hypertension, atherosclerosis, and neurodegenerative diseases [26]. MG has been postulated to play a role in the development of hypertension [27]. Studies using animal model and cell cultures showed a significant increase in blood pressure to coincide with elevated MG level in plasma and aortic tissues [28]. However, functional links between MG biogenesis and hypertension, in part mediated by ROS and AGEs, have only been documented in rat model but not yet in humans under these conditions.

MG is an endogenous metabolite formed in virtually all mammalian cells primarily from the triosephosphate intermediates of glucose metabolism. Other important precursors for MG generation include aminoacetone and ketone bodies from protein catabolism and fatty acid oxidation, respectively. Several enzymatic or nonenzymatic reactions are involved in MG formation from these precursors. Enzymatic formation of MG includes reactions catalyzed by 3 kinds of enzymes: methylglyoxal synthase, cytochrome P450 2E1 (CYP 2E1), and semicarbazide sensitive amine oxidase (SSAO) [26].

The main nonenzymatic reaction for MG formation is the spontaneous degradation of triosephosphate intermediates in glucose metabolism, DHAP and glyceraldehyde-3-phosphate (GA3P). Any pathways that increase glycolytic flux and triosephosphate formation are possibly linked to $\mathrm{MG}$ formation, such as the glycolysis pathway under physiological conditions and the activated polyol-fructose pathway under hyperglycemic conditions [26].

The average levels of $\mathrm{H}_{2} \mathrm{O}_{2}$ and AOPP are presented in Table II.

TABLE II: $\mathrm{H}_{2} \mathrm{O}_{2}$ AND AOPP LEVELS COMPARISON RESULT

\begin{tabular}{cccc}
\hline \hline Parameters & Control Group & Case Group & $P$ values \\
\hline $\mathrm{H}_{2} \mathrm{O}_{2}$ & $4,149 \pm 1,105$ & $36,488 \pm 12,64$ & 0,000 \\
& 3 & \\
AOPP & $5,319 \pm 2,540$ & $9,360 \pm 1,727$ & 0,000 \\
\hline \hline
\end{tabular}

Mann-Whitney test results showed (Table II) that there were significant differences between case and control groups $(p<0.05)$.

Environmental stresses are known to induce hydrogen peroxide and other toxic oxygen species production in cellular compartments and result in acceleration of lipid peroxidation and other oxidative damage. Hydrogen peroxide being a strong oxidant can initiate localized oxidative damage in cells leading to disruption of metabolic function and loss of cellular integrity resulting in senescence promotion. It also changes the redox status of surrounding cells [27].

In human, hydrogen peroxide is produced in many different cell types, including fibroblast, vascular endothelial, smooth muscle, and inflammatory cells . It is known to act as a cellular signaling molecule within blood vessels, and it plays key roles in regulating vascular smooth muscle cell (VSMC) growth differentiation, migration, and vascular inflammation. Hydrogen peroxide has been shown to cause constriction in a variety of vascular beds under quiescent conditions, and it can induce vasoconstriction in a number of arteries in vitro, including rat aorta, vena cava and pulmonary artery, canine basilar artery, and human placental arteries [28].

$\mathrm{H}_{2} \mathrm{O}_{2}$ is an even less reactive species that is uncharged and can diffuse across membranes through aquaporins. Despite its low reactivity, some proteins contain specific cysteine residues that are prone to oxidation by hydrogen peroxide, 
which are critical to hydrogen peroxide-based signaling systems. $\mathrm{H}_{2} \mathrm{O}_{2}$ can be converted to the radical hydroxyl, a highly reactive species. Hydrogen peroxide is the substrate for the majority of the antioxidant systems in the cell. These antioxidant systems are required to minimize the reaction controlling the conversion of $\mathrm{H}_{2} \mathrm{O}_{2}$ to radical hydroxyl [29].

Another type of oxidative modification of protein is AOPPs. AOPPs are produced during oxidative stress as a result of myeloperoxidase activity in activated neutrophils acting on hypochloric acid and chloramines; these are a reliable marker to measure the oxidative modification of proteins [30]. Myeloperoxidase is an haeme-containing enzyme which secreted by the phagocytes after an activation from respiratory burst system. Myeloperoxidases are usually used as tissues neutrophil accumulation and neutrophil activity marker on plasma assays. Myeloperoxidase use hydrogen peroxides to oxidize amount of aromatic species (RH) by one electron mechanism to form aromatic radical $\left(\mathrm{R}^{\bullet}\right)$. This is typical, therefore they are ready to oxidize the strong non radical reactive oxygen species, the $\mathrm{HOCl}$ ions. $\mathrm{HOCl}$ is reactive oxygen species that produced by neutrophils and very bactericidals [19].

The oxidative modifications of proteins are more stable than lipids, making proteins good oxidative stress markers. Protein oxidation can result from the formation of protein carbonyls, formation of cross linked molecules by sulphydryl group oxidation, and formation of advanced oxidation protein products (AOPPs). AOPPs can be defined as dityrosine that includes cross linked proteins. This definition is important because it excludes protein aggregates that are formed as a result of disulphide bonding. Therefore, AOPPs may have a function as a marker for oxidative stress [31].

AOPP has used recently as oxidative stress marker for several disease. The involvement of AOPPs on oxidative stress has used as marker for chronic renal failure, acute coronary syndrome, liver cirrhosis, and nasal polyposis [32]-[35].

\section{CONCLUSION}

It can be concluded from presented results that $\mathrm{Cd}$ induced damage in ovarian rat cells by increased of $\mathrm{MG}, \mathrm{CC}, \mathrm{H}_{2} \mathrm{O}_{2}$ and AOPP levels.

\section{ACKNOWLEDGMENT}

Authors are thankful to Iskandar, Dr. Research Unit Mutiara Bunda Mother and Child Hospital, Martapura South Kalimantan Indonesian, for his support and encouragement during the process of writing this research.

\section{REFERENCES}

[1] R. Wittman and H. Hu, "Cadmium exposure and nephropathy in a 28-year-old female metals worker," $E H P$, vol. 110, pp. 1261-1266, 2002.

[2] E. Suhartono, Triawanti, A. Yunanto, R. T. Firdaus, and Iskandar, "Chronic Cadmium hepatooxidative in rats: Treatment with Haruan fish (Channa striata) extract," APCBEE Procedia, vol. 5, pp. 441 445, 2013.

[3] A. Bernard, "Cadmium \& Its adverse effects on human health," IJMR, vol. 128, pp. 557-564, Oct. 2008.

[4] P. Massanyi, V. Uhrin, R. Toman, J. Pivko, N. Luka, Z. S. Forgacs, Z. Somosy, M. Fabi, and J. Danko, "Ultrastructural changes of ovaries in rabbits following cadmium administration," Acta. Vet. Brno, vol. 74 pp. 29-35, 2005

[5] P. Nad, P. Massanyi, M. Skalicka, B. Korenekova, and V. Cigankova, "The effect of cadmium in combination with zinc and selenium on ovarian structure in Japanese quails," Rizikové faktory potravového ret'azca, vol. v, 2005.

[6] P. A. Voziyan, R. G. Khalifah, C. Thibaudeau, A. Yildiz, J. Jacob, A. S. Serianni, and B. G. Hudson, "Modification of proteins in vitro by physiological levels of glucose," $J B C$, vol. 278, no. 47, pp. 46616-46624, Nov. 2003.

[7] T. W. C. Lo, M. E. Westwood, A. C. Mclellan, T. Selwood, and P. J. Thornalleys, "Binding and modification of proteins by methylglyoxal under physiological conditions: A kinetic and mechanistic study with Na-Acetylarginine, Na-Acetylcysteine, and Na- Acetyllysine, and bovine serum albumin," JBC, vol. 269, no. 51, pp. 32299-32305, Dec. 1994

[8] A. I. Ledesma-Osuna, G. Ramos-Clamont, and L. Vázquez-Moreno, "Characterization of bovine serum albumin glycated with glucose, galactose and lactose," $A B P$, vol. 55, no. 3, pp. 491-497, 2008.

[9] D. Tan, Y. Wang, C. Lo, and C.-T. Ho, "Methylglyoxal: Its presence and potential scavengers," Asia Pac J Clin Nutr, vol. 17, no. S1, pp. 261-264, 2008.

[10] U. M. N. Murthy and W. Q. Sun, "Protein modification by Amadori and Maillard reactions during seed storage: Roles of sugar hydrolysis and lipid peroxidation," JXB, vol. 51, no. 348, pp. 1221-1228, July 2000.

[11] H. Yamawaki, K. Saito, M. Okada, and Y. Hara, "Methylglyoxal mediates vascular inflammation via JNKand p38 in human endothelial cells, AJP-Cell, vol. 295, pp. C1510-C1517, 2008.

[12] Y. Naito, T. Takagi, T. Oya-Ito et al., "Impaired gastric ulcer healing in diabetic mice: Role of methylglyoxal," J Physiol Pharmacol, vol. 60, Suppl. 7, pp. 123-130, 2009.

[13] Y. Nohara, A. T. Usui, B. T. Kinoshita, and M. Watanabe, "Generation of superoxide anions during the reaction of guanidino compounds with methylglyoxal," $C P B$, vol. 50, no. 2, pp. 179-184, 2002.

[14] Z. Turk, "Glycotoxines, carbonyl stress and relevance to diabetes and its complications," Physiol Res, vol. 59, pp.147-156, 2010.

[15] S. Kingkeohoi and F. W. R. Chaplen, "Analysis of methylglyoxal metabolism in cho cells grown in culture," Cytotechnology, vol. 48, pp. $1-13,2005$.

[16] J. H. Kang, "Oxidative modification of human ceruloplasmin by methylglyoxal: An in vitro study," JBMB, vol. 39, no. 3, pp. 335-338, May 2006

[17] S. H. An and J. H. Kang, "Oxidative damage of DNA induced by the reaction of methylglyoxal with lysine in the presence of ferritin," $B M B$ Reports, vol. 46, no. 4, pp. 225-229, 2013.

[18] J. Valencia, S. Weldon, and D. Quinn, "Advanced glycation end product ligand for the receptor advanced glycation end product: Biochemical characteristic and formation kinetic," Analytic Biochem, vol. 324, pp. 68-78, 2004.

[19] A. Yunanto, H. M. S. C. Kusuma, E. Widjajanto, and M. A. Widodo, "Kuantitas, kualitas, dan daya fagositosis neutrofil pada saliva dan darah bayi baru lahir dengan faktor risiko sepsis," $J K B$, vol. 27, no. 2 , Aug. 2012.

[20] A. Yunanto, P. Andayani, Triawanti, E. Suhartono, and M. A. Widodo, "Neutrophil phagocytosis activity compared to myeloperoxidase, hydrogen peroxidase and lactoferrin levels in saliva of newborn baby with sepsis risk factor to detect early-onset neonatal sepsis," IJPSI, vol. 2, pp. 18-22, Jan. 2013.

[21] U. K. Mishra, S. E. Jacobs, L. W. Doyle, and S. M. Garland, "Newer approaches to the diagnosis of early onset neonatal sepsis," $A D C F N$, vol. 91, pp. F208-F212, 2006.

[22] U. K. Biswas, S. Banerjee, A. Das, and A. Kumar, "Elevation of serum methylglyoxal may be used as a screening marker in oral premalignant lesions," Biomed Res, vol. 22, no. 3, pp. 273-278, 2011.

[23] D. Banerjee, P. A. Kumar, B. Kumar, U. K. Madhusoodanan, S. Nayak, and J. Jacob, "Determination of absolute hydrogen peroxide concentration by spectrophotometric method," Current Science, vol. 83 , no. 10 , Nov. 2002.

[24] J. Zuwata-Jagietto, M. Pazgan-Simon, K. Simon, and M. Warwas, "Advanced oxidation products and inflammatory markers in liver cirrhosis: a comparison between alcohol-related and HCV-related cirrhosis," Acta BP, vol. 58, no. 1, pp. 59-65, Mar 2011.

[25] E. M. Ellis, "Reactive carbonyls and oxidative stress: potential for therapeutic intervention," Pharmacology \& Therapeutics, vol. 115, pp. 13-24, 2007.

[26] K. M. Desai, T. Chang, H. Wang, A. Banigesh, A. Dhar, J. Liu, A. Untereiner, and $\mathrm{L}$. Wu, "Oxidative stress and aging: is methylglyoxal 
the hidden enemy," Can. J. Physiol. Pharmacol, vol. 88, pp. 273-284, 2010.

[27] T. Chang and L. Wu, "Methylglyoxal, oxidative stress, and hypertension," CJPP, vol. 84, pp. 1229-1238, 2006.

[28] X. Wang, K. Desai, T. Chang, and L. Wu, "Vascular methylglyoxal metabolism and the development of hypertension," J Hypertens, vol 23, pp. 1565-1573, 2005.

[29] P. Newsholme, E. Rebelato, F. Abdulkader, M. Krause, A. Carpinelli, and R. Curi, "Reactive oxygen and nitrogen species generation, antioxidant defenses, and $\beta$-cell function: a critical role for amino acids," Journal of Endocrinology, vol. 214, pp. 11-20, 2012.

[30] J. M. Moreno, I. Rodriguez Gomez, R. Wangensteen, R. Perez-Abud, J. Duarte, A. Osuna, and F. Vargas, "Mechanisms of hydrogen peroxide vasoconstriction in the isolated perfused rat kidney," Physiol Pharmacol, vol. 61, no. 3, pp. 325-332, 2010.

[31] I. Dalle-Donne, R. Rossi, D. Giustarini, A. Milzani, and R. Colombo, "Protein carbonyl groups as biomarkers of oxidative stress," Clinica Chimica Acta, vol. 329, pp. 23-38, 2003.

[32] B. Veyseller, F. Aksoy, B. Ertas, M. Keskin, O. Ozhuran, Y. S. Yilldirum, F. G. I. Bayraktar, and H. Ozturk, "A new oxidative stress marker in patients with nasal polyposis: Advance oxidation protein products (AOPP)," B-ENT, vol. 6, pp. 105-109, 2010.

[33] M. Skvarilova, A. Bulava, D. Stejskal, S. Adamovska, and J. Bartek, "Increased level of advanced oxidation protein products (AOPP) as a marker of oxidative stress in patients with acute coronary syndrome," Biomed. Papers, vol. 149, no. 1, pp. 83-87, June 2005.

[34] V. Witko-Sarsat, M. Friedlander, T. N. Khoa, C. Capeillere-Blandin, A. T. Nguyen, S. Canteloup, J. M. Dayer, P. Junger, T. Drueke, and B. Descamps-Latschka, "Advanced oxidation protein products as novel mediators on inflammation and monocyte activation in chronic renal failure," J Immunol, vol. 161, pp. 2524-2532, 1998.

[35] S. Cherian, S. Jameson, C. Rajarajeswari, V. Helena, L. L. A. Rekha, S. Raju, P. G. Kini, and A. Rao, "Oxidative stress in sepsis in children," IJMR, vol. 125, pp. 143-148, Feb. 2007.

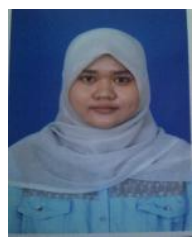

Annisa Halida Husna was born in Surabaya East Java, Indonesia, in January 1992. She is currently pursuing her medical doctor degree in Faculty of Medicine Lambung Mangkurat University, Banjarbaru, Indonesia.

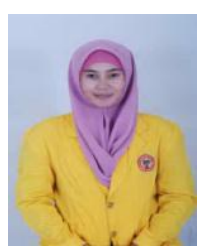

Endah Ayu Rahmadhani was born in Bontang East Kalimantan, Indonesia, in May 1992. She is currently pursuing her medical doctor degree in Faculty of Medicine Lambung Mangkurat University, Banjarbaru, Indonesia.

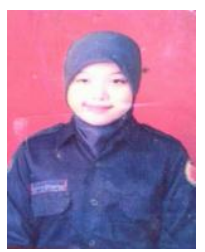

Eva Damayanti Tumbelaka was born in Banjarmasin South Kalimantan, Indonesia, in August 1992. She is currently pursuing her medical doctor degree in Faculty of Medicine Lambung Mangkurat University, Banjarbaru, Indonesia.

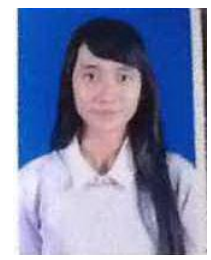

Alvita Fani Yulita was born in Surabaya East Java, Indonesia, in July 1992. She is currently pursuing her medical doctor degree in Faculty of Medicine Lambung Mangkurat University, Banjarbaru, Indonesia.

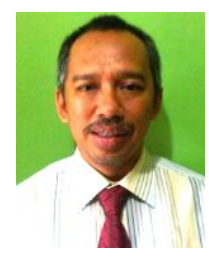

Eko Suhartono was born in Surabaya, Indonesia, in September 1968. He received his bachelor degree from Sepuluh Nopember of Institute Technology in 1991 and M.Sc degree in 1998 from Gadjah Mada University, Yogyakarta, Indonesia. He is currently studying environmental science and technology graduate program in Brawijaya University, Malang, Indonesia. His research is mainly focused on free radical and natural product antioxidant, ecotoxicology. He has published more than 40 scientific journal or conference papers. 